\title{
Adipocytes cause leukemia cell resistance to daunorubicin via oxidative stress response
}

\author{
Xia Sheng ${ }^{1}$, Jonathan Tucci $^{1}$, Jean-Hugues Parmentier ${ }^{1}$, Lingyun $\mathrm{Ji}^{2}$, James $\mathbf{W}$. \\ Behan $^{1}$, Nora Heisterkamp ${ }^{3,4,5}$, Steven D. Mittelman ${ }^{1,4,6}$ \\ ${ }^{1}$ Diabetes and Obesity Program, Center for Endocrinology, Diabetes and Metabolism, Children's Hospital Los Angeles, Los \\ Angeles, CA, USA \\ ${ }^{2}$ Department of Biostatistics, Children's Hospital Los Angeles, Los Angeles, CA, USA \\ ${ }^{3}$ Division of Hematology/Oncology and Bone Marrow Transplant, Children's Hospital Los Angeles, Los Angeles, CA, USA \\ ${ }^{4}$ Department of Pediatrics, Keck School of Medicine, University of Southern California, Los Angeles, CA, USA \\ ${ }^{5}$ Department of Pathology, Keck School of Medicine, University of Southern California, Los Angeles, CA, USA \\ ${ }^{6}$ Departments of Physiology and Biophysics, Keck School of Medicine, University of Southern California, Los Angeles, CA, USA
}

Correspondence to: Steven D. Mittelman, email: smittelman@chla.usc.edu

Keywords: $A L L$, adipocyte, oxidative stress, glutathione, drug resistance

Received: February 11, $2016 \quad$ Accepted: September 19, $2016 \quad$ Published: September 26, 2016

\section{ABSTRACT}

Adipocytes promote cancer progression and impair treatment, and have been shown to protect acute lymphoblastic leukemia (ALL) cells from chemotherapies. Here we investigate whether this protection is mediated by changes in oxidative stress. Co-culture experiments showed that adipocytes protect ALL cells from oxidative stress induced by drugs or irradiation. We demonstrated that ALL cells induce intracellular ROS and an oxidative stress response in adipocytes. This adipocyte oxidative stress response leads to the secretion of soluble factors which protect ALL cells from daunorubicin (DNR). Collectively, our investigation shows that ALL cells elicit an oxidative stress response in adipocytes, leading to adipocyte protection of ALL cells against DNR.

\section{INTRODUCTION}

Excess body weight contributes to as many as 1 out of 5 of all cancer-related deaths [1]. A landmark paper by Calle et al. found a significant association between obesity and mortality from many types of cancer [2]. Many solid tumors reside in locations rich with adipocytes, including breast, ovarian, pancreatic, colon, and prostate cancers, and some studies have shown that adipocytes interact with cancer cells [3-6]. Obesity has also shown to be associated with poorer event-free survival in the hematological cancer, acute lymphoblastic leukemia (ALL) [7-9], and we and others have demonstrated that leukemia/lymphoma cells can be found in close proximity to adipocytes in the bone marrow [10-12] and adipose tissue [13-15]. We also showed that adipocytes protect ALL cells from a variety of chemotherapeutic agents, though the mechanisms of this protection remain unclear $[16,17]$. Here, we investigate the role of adipocytes in alleviating oxidative stress caused by chemotherapy treatment in ALL cells.

Cancer cells contain increased intracellular reactive oxygen species (ROS) due to metabolic and signaling aberrations $[18,19]$. This increased ROS can have both beneficial and detrimental effects [20,21]. Cancer cells maintain a balance of ROS by activation of oxidative stress response genes, many of which are regulated by the transcription factor nuclear factor erythroid 2-related factor 2 (Nrf2) [22, 23]. The increased expression of oxidative stress response genes contributes to cancer cell resistance to chemotherapies such as anthracyclines $[24,25]$, which work in part by inducing oxidative stress. Given the significant protection that adipocytes provide to ALL cells, particularly against the anthracycline daunorubicin (DNR) [16], we investigated whether adipocytes protect ALL cells from chemotherapies by relieving oxidative stress.

\section{RESULTS}

Adipocytes protect ALL cells from oxidative stress-induced cell death

We have previously reported that murine 3T3-L1 adipocytes protect murine ALL cells (8093) [26] from 
DNR in a direct co-culture system [16]; however, we did not test whether protection against DNR requires cellcell contact, nor did we test whether this occurs with human ALL cell lines. Therefore, we cultured $\sim 2 \times 10^{5}$ mouse (8093) and human (BV173, RS4;11, and Nalm6) ALL cells in TransWells above 3T3-L1 adipocytes, preadipocytes (fibroblasts), or no feeder layer. Transwells contained polycarbonate membranes with $0.4 \mu \mathrm{m}$ pores, allowing free diffusion of media without direct cell-cell contact. Adipocytes protected mouse and human ALL cells from DNR, compared to no feeder and pre-adipocytes (Figure 1A). The human adipocyte Chub-S7 cell line also protected human ALL cells against DNR in similar transwell cultures. While 24 hours of DNR treatment led to increased cleaved caspase 3 in BV173 cells, indicating apoptosis by the intrinsic pathway, this was reversed in the presence of adipocytes (Figure 1B). 3T3-L1 adipocytes also protected BV173 ALL cells from the anthracycline doxorubicin (Figure 1C).

Our data indicates that direct cell-cell contact is not necessary for the protection against DNR, implying the existence of soluble factors mediating this protection. Surprisingly, we found that adipocyte conditioned media (ACM) did not protect ALL cells from DNR (Figure 1D). However, media conditioned by both adipocytes and leukemia cells simultaneously (ALCM) protected 8093 and BV173 from DNR treatment compared to both control media and ACM (Figure 1D), and reduced DNR induced cleavage of caspase 3 in 8093 cells (Figure 1E). Similar results were observed when media was conditioned serially by ALL cells and then adipocytes (not shown). ALCM also protected ALL cells from apoptosis as measured by Annexin $\mathrm{V}$, though this did not reach statistical significance in BV173 cells (Figure 1F). Together, these results imply that adipocytes release protective factors when stimulated by ALL cells.

Since DNR is a potent inducer of ROS [27], which contributes to its cytotoxicity, we next investigated whether adipocytes prevented DNR induction of ROS. We used DCFH-DA to directly measure intracellular ROS in Nalm6 cells during DNR treatment. DNR induced intracellular ROS within 6 hours in a dose-dependent manner, and this was significantly reduced in the presence of adipocytes, but not fibroblasts (Figure 2A). A similar pattern was observed in using the dye CellRox ${ }^{\circledR}$, which demonstrated that ALCM protected all three human ALL cell lines from the DNR induction of intracellular ROS (Figure 2B). ALL cells exhibited an oxidative stress response after DNR treatment, as demonstrated by an increase in gene expression of the two subunits of the glutathione producing enzyme, glutamate cysteine ligase (GCLC and GCLM, Figure 2C). However, coculturing with either 3T3-L1 or Chub-S7 adipocytes reversed the induction of these oxidative stress response genes (Figure 2C). Interestingly, expression of both genes decreased slightly, but significantly, in 8093 cells co-cultured with adipocytes without DNR treatment (black bar vs. white bar), potentially indicating alleviation of the basal level of oxidative stress. A similar pattern of GCLC and GCLM expression was also observed with Nalm6 ALL cells (data not shown).

To test whether adipocyte protection of ALL cells from oxidative stress was specific to that induced by DNR, we used additional inducers of oxidative stress. ALL cells were treated with chaetocin, a fungal-derived toxin that inhibits thioredoxin reductase-1, leading to increased cellular oxidative stress. Adipocytes significantly protected all three ALL cell lines from chaetocin induced cell death (Figure 2D). We also found that co-culturing with adipocytes modestly improved the viability of BV173 ALL cells that had been irradiated with 12 and 18 Gy (Figure 2E), though in this case adipocytes did not offer significantly more protection than pre-adipocytes. Although both chaetocin and irradiation cause insults besides just oxidative stress, these results are consistent with the findings that adipocytes protect ALL cells from oxidative stress induced cytotoxicity.

\section{ALL cells induce oxidative stress in adipocytes}

To investigate how ALL cells stimulate adipocytes to secrete protective factors, we exposed adipocytes to leukemia cell conditioned media (LCM) for 24 hours, and performed Affymetrix microarray analysis on the adipocytes. We found 3,528 significant gene expression changes $(p<0.05)$ in the adipocytes, including upregulation of many genes in the oxidative stress response pathway (Table 1 shows the top 10 most upregulated genes, ranked by fold change). Ingenuity Pathway Analysis (IPA) identified the Nrf2-mediated oxidative stress response to be one of the most affected pathways in adipocytes, with 47 genes differentially regulated down-stream of the pathway (Ingenuity ${ }^{\circledR}$ Systems, www.ingenuity.com, Table 2), implying that ALL cells were inducing oxidative stress in adipocytes. To directly test whether ALL cells induce oxidative stress in adipocytes, we visualized adipocyte intracellular ROS with DCFH-DA using fluorescence confocal microscopy. After 48 hours of co-culture with BV173 cells in a TransWell system, adipocytes had increased intracellular ROS (Figure 3A and 3B), to a similar degree as adipocytes treated with buthionine sulfoximine (BSO) as a positive control. Co-culture with ALL cells also induced a significant upregulation of the oxidative stress response genes, HO-1 and ADM, and a non-statistically significant increase in Mt2 gene expression (Figure 3C), as well as increased HO-1 protein levels (Figure 3D), confirming our microarray findings. Consistent with this, glutathione concentration in media conditioned by 3T3-L1 adipocytes together with BV173 ALL cells for 48 hours was higher than media conditioned by adipocytes or leukemia cells alone (Figure 3E). 


\section{ALL cell induction of oxidative stress in adipocytes induces their protection of ALL cells from DNR}

To test whether ALL induction of oxidative stress response in adipocytes induces their protection of ALL cells, we treated adipocytes with cobolt chloride, a hypoxia mimetic which stabilizes HIF $1 \alpha$ and induces an antioxidant response [28]. $\mathrm{CoCl}_{2}$ treatment was associated with increase in adipocyte HIF- $1 \alpha$ protein levels and gene expression of HO-1, GCLC, and GCLM (Figure 4A and 4B). 3T3-L1 and ChubS7 conditioned media made in the presence of $30 \mu \mathrm{M}$ cobalt chloride $\left(\mathrm{w} / \mathrm{CoCl}_{2}\right)$ were protective of ALL cells against DNR, compared to both
A

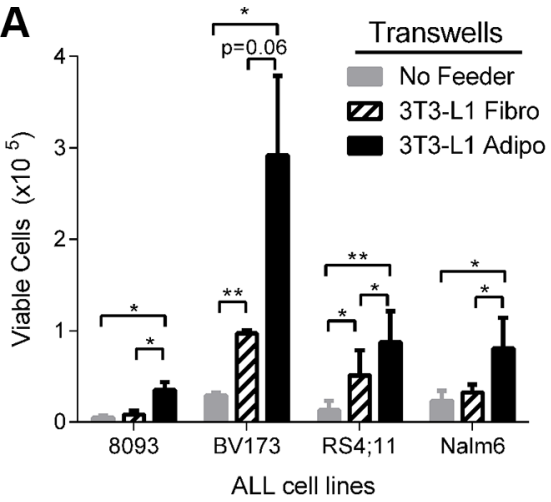

C

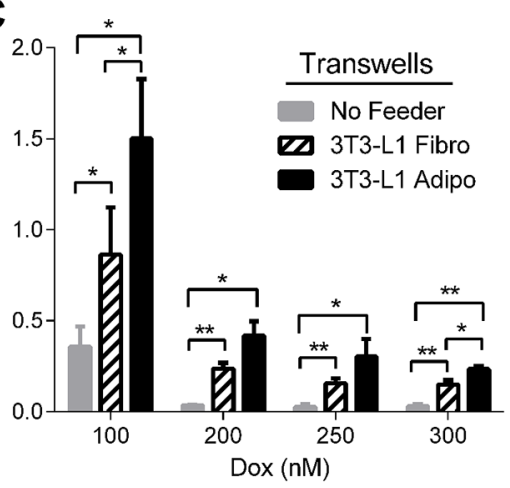

B

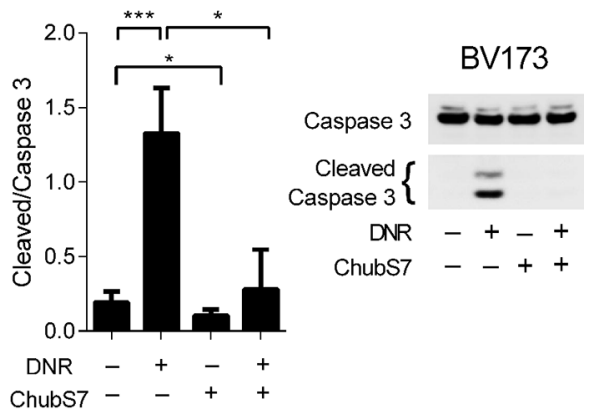

E

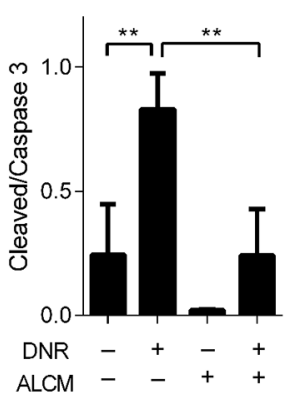

$\mathbf{F}$

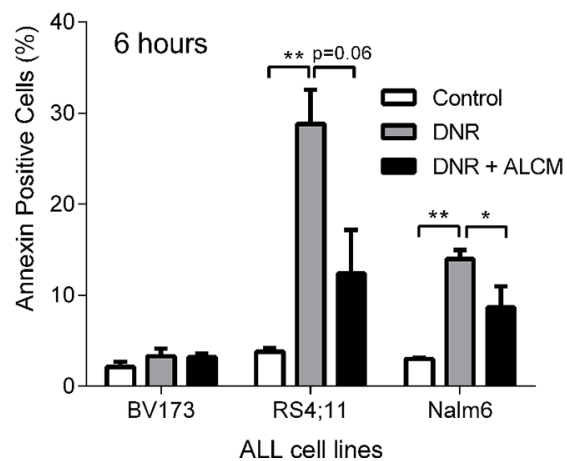

D

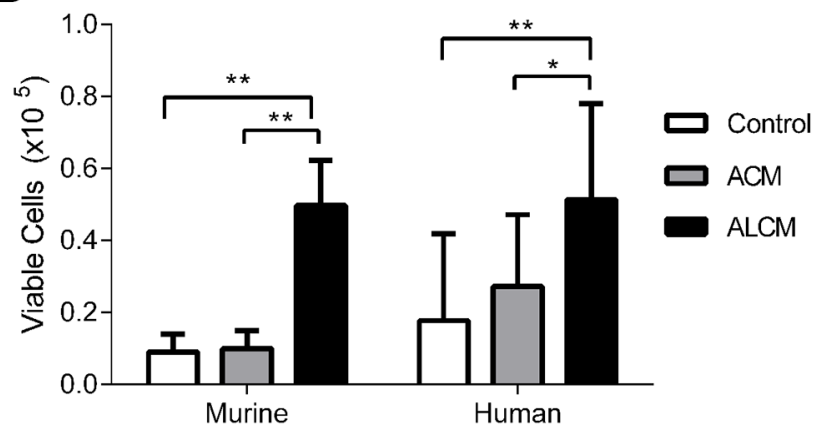

$\frac{\text { Transwells }}{\text { No Feeder }}$ Z ChubS7 Fibro Chubs7 Adipo

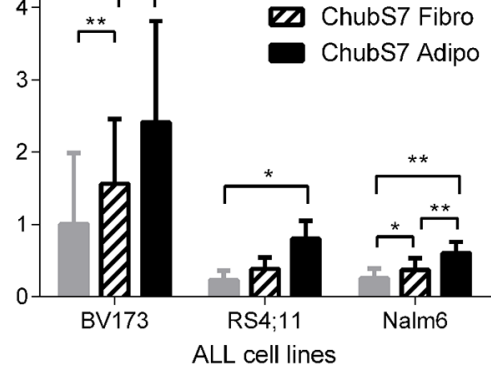

Figure 1: Adipocytes protect ALL from oxidative stress induced cell death. (A) ALL cells co-cultured in TransWells over 3T3-L1 and ChubS7 pre-adipocytes (hatched bars) and adipocytes (black bars) with 72 hour DNR treatment (8093 $35 \mathrm{nM}, \mathrm{BV} 173100 \mathrm{nM}$, RS4;11 $100 \mathrm{nM}$, and Nalm6 $200 \mathrm{nM}$ ). No feeder condition is where ALL cells were cultured alone $(n=3-5)$. (B) One representative image of western blot of Caspase $3(37 \mathrm{kDa})$ and cleaved caspase $3(19$ and $17 \mathrm{kDa})$ in BV173 cells treated with DNR for 24 hours in the presence or absence of adipocytes. Images were histogram stretched in a consistent manner to increase brightness for publication. Quantification of the ratio of cleaved (both bands) over total caspase 3 (band at $37 \mathrm{kDa}$ ) is shown on the right $(n=3)$. (C) BV173 ALL cells cultured over 3T3-L1 cells and treated with various doses of doxorubicin (Dox). (D) 8093 cells treated with $35 \mathrm{nM}$ DNR in 3T3-L1 ACM and ALCM (left, $n=6$ ); BV173 cells treated with $100 \mathrm{nM}$ DNR in ChubS7 ACM and ALCM (right, $n=5$ ). (E) Quantification of cleaved over total caspase 3 of 8093 ALL cells after 24 hours treatment with $25 \mathrm{nM}$ DNR with and without ALCM. (F) Annexin V staining of human ALL cells after 24 hour exposure to DNR with or without ALCM. $* P<0.05, * * P<0.01, * * * P<0.001$ All asterisks indicate comparison to control no feeder (NF gray bar) or no DNR no adipocyte conditions (white bar) unless otherwise indicated. 
ACM (Figure 4C), and ACM to which $\mathrm{CoCl}_{2}$ was added after conditioning as a control $\left(+\mathrm{CoCl}_{2}\right)$. Thus, induction of oxidative stress response by $\mathrm{CoCl}_{2}$ induces adipocytes to secrete factors which protect ALL cells from DNR.

To further hone in on which aspects of the adipocyte oxidative stress response are responsible for their protection of ALL cells against DNR, we blocked parts of the oxidative stress response in adipocytes prior to coculturing with ALL cells. BSO, an inhibitor of glutamylcysteine ligase, completely suppressed intracellular GSH levels in adipocytes, while auranofin (AUR), an inhibitor of thioredoxin reductase, actually
A

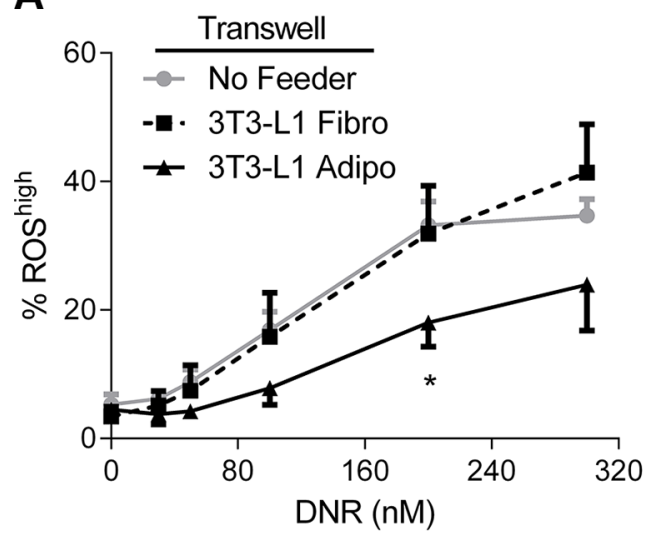

8093

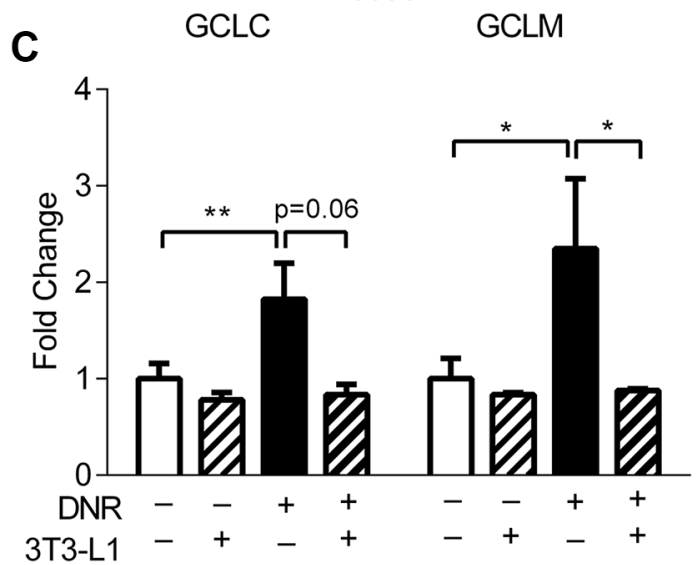

D

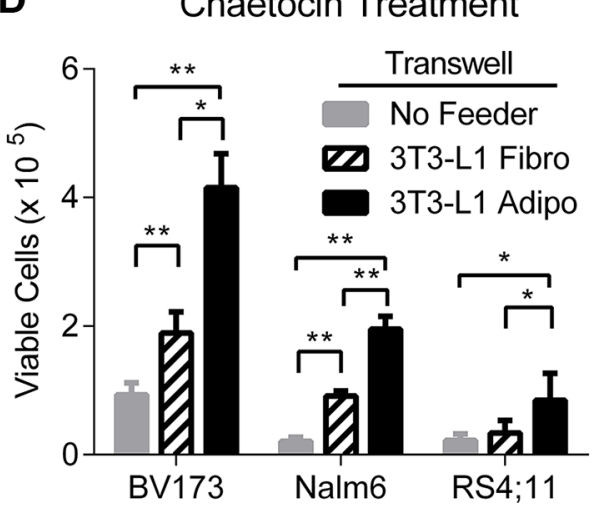

B $\square$ noDNR $\square$ DNR $\square$ DNR + ALCM

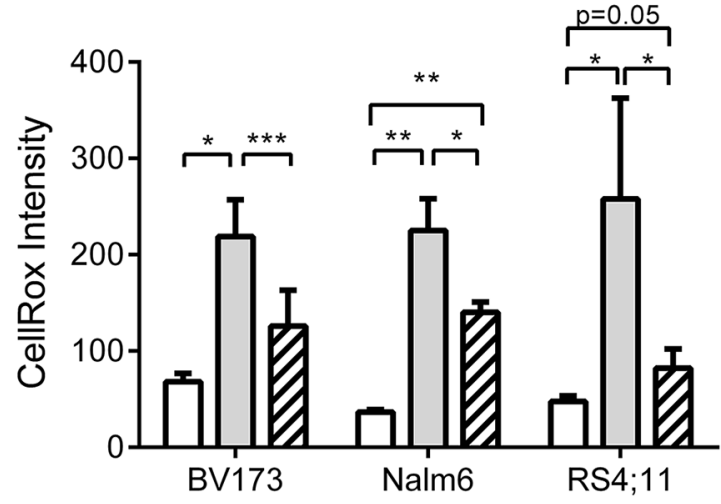

BV173

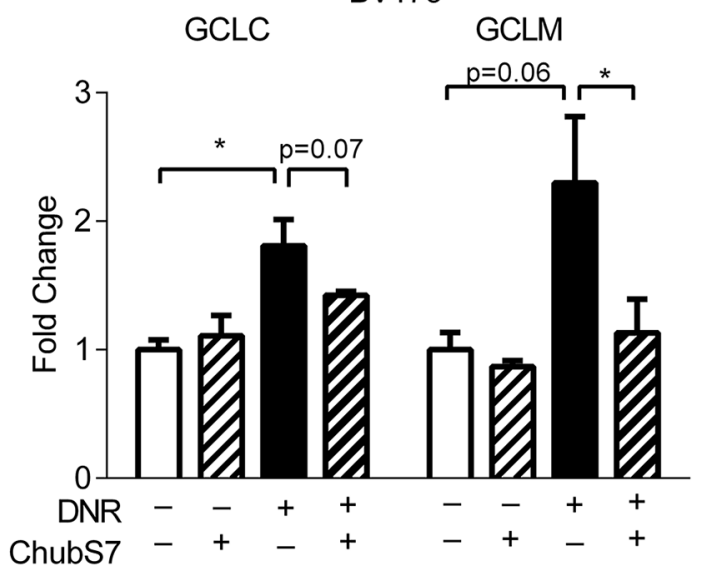

E

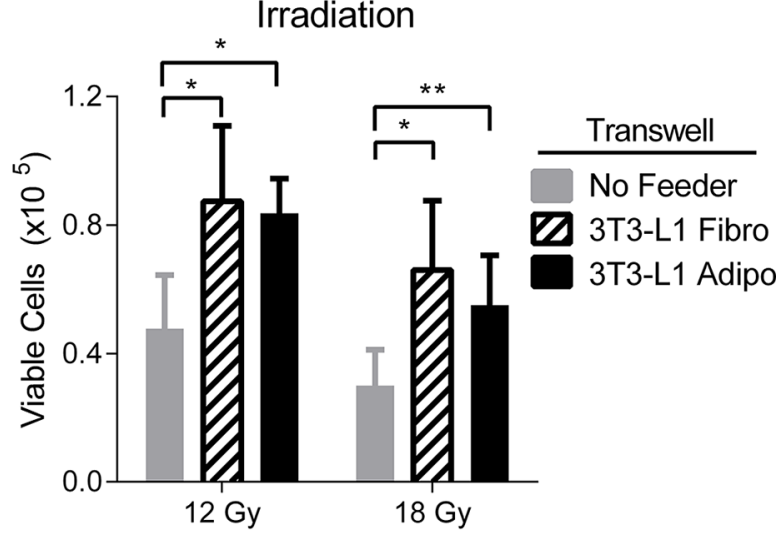

Figure 2: Adipocytes protect ALL cells from oxidative stress. (A) Measurement of \% ROS ${ }^{\text {high }}$ population in Nalm6 cells treated with DNR for 6 hours. \% ROS ${ }^{\text {high }}$ based on gates defined by cells without DNR treatment. Adipo condition is significantly different than both Fibro and No Feeder by repeated measure ANOVA $(p<0.05)$. (B) CellRox ${ }^{\circledR}$ intensity by flow cytometry measures intracellular ROS after 24 hours exposure to DNR or DNR plus ALCM. (C) GCLC and GCLM gene expressions by qPCR in 8093 and BV173 cells treated with DNR, with or without adipocytes present $(n=3)$. Asterisks and $p$-values indicate comparisons to the no-daunorubicin, no 3T3-L1 condition (white bar), unless otherwise noted. (D) ALL cells co-cultured with 3T3-L1 pre-adipocytes and adipocytes with chaetocin treatment (BV173 and Nalm6 $100 \mathrm{nM}, \mathrm{RS} 4 ; 1150 \mathrm{nM}, n=3-4)$. (E) Irradiated BV173 ALL cells co-cultured with 3T3-L1 pre-adipocytes and adipocytes $(n=3)$. $* P<0.05, * * P<0.01, * * * P<0.001$. 
Table 1: Top 10 most upregulated genes ranked by fold change from Affymetrix microarray analysis of data comparing gene expression changes in 3T3-L1 adipocytes exposed to LCM for 24 hours to control 3T3-L1 adipocytes

\begin{tabular}{l|l|c|l|}
\hline \multicolumn{1}{c}{ Gene symbol } & \multicolumn{2}{c}{ Fold change } & \multicolumn{1}{c}{$P$-value } \\
\hline Mt2 & Metallothionein 2 & 4.6 & 0.02 \\
\hline Aldh112 & Aldehyde dehydrogenase 1 family, member 12 & 3.6 & 0.00004 \\
\hline Adm & Adrenomedullin & 3.5 & 0.0006 \\
\hline Trib3 & Induced in fatty liver dystrophy 2 & 3.1 & 0.002 \\
\hline Eno2 & Enolase 2, gamma neuronal & 3.0 & 0.00002 \\
\hline Hmox1 & Heme oxygenase (decycling) 1 & 2.7 & 0.0001 \\
\hline Ddit3 & Dna-damage inducible transcript 3 & 2.7 & 0.0003 \\
\hline Myd116 & Myeloid differentiation primary response gene 116 & 2.6 & 0.0003 \\
\hline Car6 & Carbonic anhydrase 6 & 2.5 & 0.004 \\
\hline Got1 & Glutamate oxaloacetate transaminase 1, soluble & 2.5 & 0.003 \\
\hline
\end{tabular}

Table 2: Forty-seven differentially regulated genes in the Nrf-2 mediated oxidative stress response pathway identified by IPA

\begin{tabular}{|c|c|c|c|}
\hline Symbol & Entrez gene name & Fold change & $p$-value \\
\hline HMOX1 & heme oxygenase (decycling) 1 & 2.738 & $1.30 \mathrm{E}-04$ \\
\hline GCLC & glutamate-cysteine ligase, catalytic subunit & 2.020 & $2.40 \mathrm{E}-03$ \\
\hline $\mathrm{ABCC} 1$ & ATP-binding cassette, sub-family C (CFTR/MRP), member 1 & 2.007 & $1.63 \mathrm{E}-03$ \\
\hline NQO1 & $\mathrm{NAD}(\mathrm{P}) \mathrm{H}$ dehydrogenase, quinone 1 & 1.999 & $3.85 \mathrm{E}-03$ \\
\hline FMO1 & flavin containing monooxygenase 1 & -1.779 & $2.97 \mathrm{E}-03$ \\
\hline ATF4 & activating transcription factor 4 & 1.740 & $4.28 \mathrm{E}-04$ \\
\hline PIK3R3 & phosphoinositide-3-kinase, regulatory subunit 3 (gamma) & -1.734 & $6.34 \mathrm{E}-03$ \\
\hline MAFF & v-maf avian musculoaponeurotic fibrosarcoma oncogene homolog F & 1.618 & $1.54 \mathrm{E}-02$ \\
\hline MGST3 & microsomal glutathione S-transferase 3 & -1.569 & $5.49 \mathrm{E}-03$ \\
\hline GCLM & glutamate-cysteine ligase, modifier subunit & 1.541 & $1.19 \mathrm{E}-03$ \\
\hline EPHX1 & epoxide hydrolase 1, microsomal (xenobiotic) & 1.502 & $9.86 \mathrm{E}-04$ \\
\hline ACTG2 & actin, gamma 2 , smooth muscle, enteric & -1.493 & $2.22 \mathrm{E}-02$ \\
\hline HERPUD1 & $\begin{array}{l}\text { homocysteine-inducible, endoplasmic reticulum stress-inducible, } \\
\text { ubiquitin-like domain member } 1\end{array}$ & 1.484 & $7.61 \mathrm{E}-03$ \\
\hline MAP3K1 & $\begin{array}{l}\text { mitogen-activated protein kinase kinase kinase 1, E3 ubiquitin protein } \\
\text { ligase }\end{array}$ & 1.477 & $3.31 \mathrm{E}-03$ \\
\hline ACTA2 & actin, alpha 2, smooth muscle, aorta & -1.440 & $1.53 \mathrm{E}-02$ \\
\hline SQSTM1 & sequestosome 1 & 1.435 & $8.34 \mathrm{E}-04$ \\
\hline MAFG & v-maf avian musculoaponeurotic fibrosarcoma oncogene homolog $\mathrm{G}$ & 1.431 & $3.91 \mathrm{E}-02$ \\
\hline PRKCD & protein kinase $\mathrm{C}$, delta & 1.428 & 3.99E-03 \\
\hline TXNRD1 & thioredoxin reductase 1 & 1.414 & $2.83 \mathrm{E}-03$ \\
\hline HSPB8 & heat shock $22 \mathrm{kDa}$ protein 8 & 1.413 & $3.38 \mathrm{E}-04$ \\
\hline MAP2K1 & mitogen-activated protein kinase kinase 1 & 1.408 & $1.56 \mathrm{E}-04$ \\
\hline PIK3R1 & phosphoinositide-3-kinase, regulatory subunit 1 (alpha) & -1.406 & $1.68 \mathrm{E}-02$ \\
\hline DNAJA3 & DnaJ (Hsp40) homolog, subfamily A, member 3 & 1.398 & $3.47 \mathrm{E}-03$ \\
\hline SCARB1 & scavenger receptor class B, member 1 & -1.374 & $2.06 \mathrm{E}-02$ \\
\hline GSTO1 & glutathione S-transferase omega 1 & 1.362 & $2.05 \mathrm{E}-02$ \\
\hline DNAJC15 & DnaJ (Hsp40) homolog, subfamily C, member 15 & -1.301 & $3.46 \mathrm{E}-02$ \\
\hline
\end{tabular}




\begin{tabular}{|l|l|c|c|}
\hline MAPK7 & mitogen-activated protein kinase 7 & 1.284 & $1.06 \mathrm{E}-02$ \\
\hline CAT & catalase & -1.271 & $1.84 \mathrm{E}-02$ \\
\hline DNAJB2 & DnaJ (Hsp40) homolog, subfamily B, member 2 & 1.262 & $2.98 \mathrm{E}-02$ \\
\hline DNAJC16 & DnaJ (Hsp40) homolog, subfamily C, member 16 & 1.247 & $2.02 \mathrm{E}-02$ \\
\hline DNAJC8 & DnJ (Hsp40) homolog, subfamily C, member 8 & 1.228 & $1.41 \mathrm{E}-02$ \\
\hline ENC1 & ectodermal-neural cortex 1 (with BTB domain) & -1.203 & $1.06 \mathrm{E}-02$ \\
\hline DNAJC18 & DnaJ (Hsp40) homolog, subfamily C, member 18 & 1.203 & $2.90 \mathrm{E}-02$ \\
\hline GSTM2 & glutathione S-transferase mu 2 (muscle) & -1.199 & $2.73 \mathrm{E}-02$ \\
\hline FTH1 & ferritin, heavy polypeptide 1 & 1.195 & $3.25 \mathrm{E}-02$ \\
\hline PIK3CA & phosphatidylinositol-4,5-bisphosphate 3-kinase, catalytic subunit alpha & 1.190 & $5.38 \mathrm{E}-03$ \\
\hline AOX1 & aldehyde oxidase 1 & -1.180 & $8.24 \mathrm{E}-03$ \\
\hline DNAJC5 & DnaJ (Hsp40) homolog, subfamily C, member 5 & 1.170 & $4.87 \mathrm{E}-02$ \\
\hline JUN & jun proto-oncogene & 1.148 & $1.33 \mathrm{E}-02$ \\
\hline GSTO2 & glutathione S-transferase omega 2 & -1.147 & $4.86 \mathrm{E}-03$ \\
\hline STIP1 & stress-induced phosphoprotein 1 & 1.144 & $2.21 \mathrm{E}-02$ \\
\hline EIF2AK3 & eukaryotic translation initiation factor 2-alpha kinase 3 & 1.138 & $4.41 \mathrm{E}-02$ \\
\hline PRKD1 & protein kinase D1 & -1.132 & $1.81 \mathrm{E}-02$ \\
\hline MAPK3 & mitogen-activated protein kinase 3 & 1.132 & $7.71 \mathrm{E}-05$ \\
\hline FOSL1 & FOS-like antigen 1 & -1.110 & $1.41 \mathrm{E}-02$ \\
\hline PIK3C3 & phosphatidylinositol 3-kinase, catalytic subunit type 3 & 1.107 & $1.44 \mathrm{E}-02$ \\
\hline DNAJC11 & DnaJ (Hsp40) homolog, subfamily C, member 11 & -1.069 & $4.86 \mathrm{E}-02$ \\
\hline
\end{tabular}

increased GSH levels, likely a compensatory effect from blocking thioredoxin synthesis (Figure 5A). Neither treatment resulted in visible morphological changes to the adipocytes. ALL cells and LCM had no measurable effect on adipocyte GSH levels. Pretreatment of 3T3-L1 adipocytes with BSO only partially reversed their ability to protect BV173 and Nalm6 against DNR (Figure 5B). Similar results were observed with ChubS7 human adipocytes (Figure 5C). However, pretreatment of 3T3-L1 adipocytes with AUR did not affect DNR protection (Figure 5D), nor did it add to the effect of BSO to reduce adipocyte protection (not shown). Taken together, these results demonstrate that GSH synthesis may partly contribute to the adipocyte's ability to protect ALL cells from DNR.

\section{Exogenous antioxidants protect ALL cells from DNR}

As a proof of principle, we next tested whether reduction of ALL cell oxidative stress alone could protect ALL cells against DNR. Supplementation with high concentration $(20 \mathrm{mM})$ of GSH significantly increased the number of viable cells after DNR treatment of BV173, Nalm6 (Figure 6A), and RS4;11 (data not shown) ALL cells. N-acetylcysteine (NAC), a GSH precursor, also protected these cells from DNR (Figure 6B), and was associated with increased viability assessed by flow cytometry (Figure 6C). NAC also partially reversed the induction of intracellular ROS caused by DNR treatment, measured by $\mathrm{CellROX}^{\circledR}$, though this did not reach statistical significance in Nalm6 cells (Figure 6C).

\section{DISCUSSION}

In the present study, we demonstrate that ALL cells induce oxidative stress in adipocytes, which causes them to protect the ALL cells from oxidative stress, in turn promoting resistance to the anthracycline, daunorubicin (DNR). These findings add to the growing literature which implicates adipocytes as an active and important component of the microenvironment of some cancers, such as breast cancer, ovarian cancer, and chronic lymphocytic leukemia $[3-6,29]$. Since adipocytes are highly prevalent in the microenvironments of these cancers (breast, peritoneum, bone marrow), this phenomenon could contribute to cancer cell resistance to chemotherapy in patients.

Our results have uncovered a two-way communication between ALL cells and adipocytes, apparently initiated by ALL cell induction of oxidative stress in adipocytes. There is an expanding literature showing that cancer cells can alter the phenotypes of cells in their microenvironment, for example by inducing the development of "cancer-associated fibroblasts" [30-32]. Some of this interaction may be mediated by 
tumor cell induction of oxidative stress in nearby stromal cells [33]. Less is known about adipocytes in the cancer microenvironment, though recent studies have described "cancer-associated adipocytes", which exhibit a modified phenotype and specific biological features [34], such as delipidation, dedifferentiation, and secretion of specific adipokines $[35,36]$. These effects may be mediated by soluble factors released by tumor cells $[37,38]$. Ours is the first study to our knowledge to identify this phenomenon between adipocytes and ALL cells.

Our findings are consistent with other literature which highlights the importance of oxidative stress to leukemia cell drug response. Inhibition of the oxidative stress response has been shown to be cytotoxic and enhance chemosensitivity of some leukemia cells [39-41]. Bone marrow stromal cells support primary ALL cell growth in vitro by providing cysteine, which maintains glutathione levels and results in protection against oxidative stress [42]. It is possible that adipocytes in bone marrow and adipose tissue provide similar protection.

While these data suggest that soluble factors mediate adipocyte protection of ALL cells from oxidative stress, we have yet to identify which factors are responsible. Among the top 10 genes upregulated in adipocytes (Table 1), adrenomedullin (ADM) is a cytokine known to be secreted by adipocytes [43], and has been shown to play a role in cell survival in several types of cancer [44]. In our hands, ADM did not protect 8093 ALL cells from DNR treatment (Supplementary Figure S1A), and neutralizing ADM antibodies did not block adipocyte protection of 8093 cells against DNR (Supplementary Figure S1B). These results excluded ADM as the relevant survival
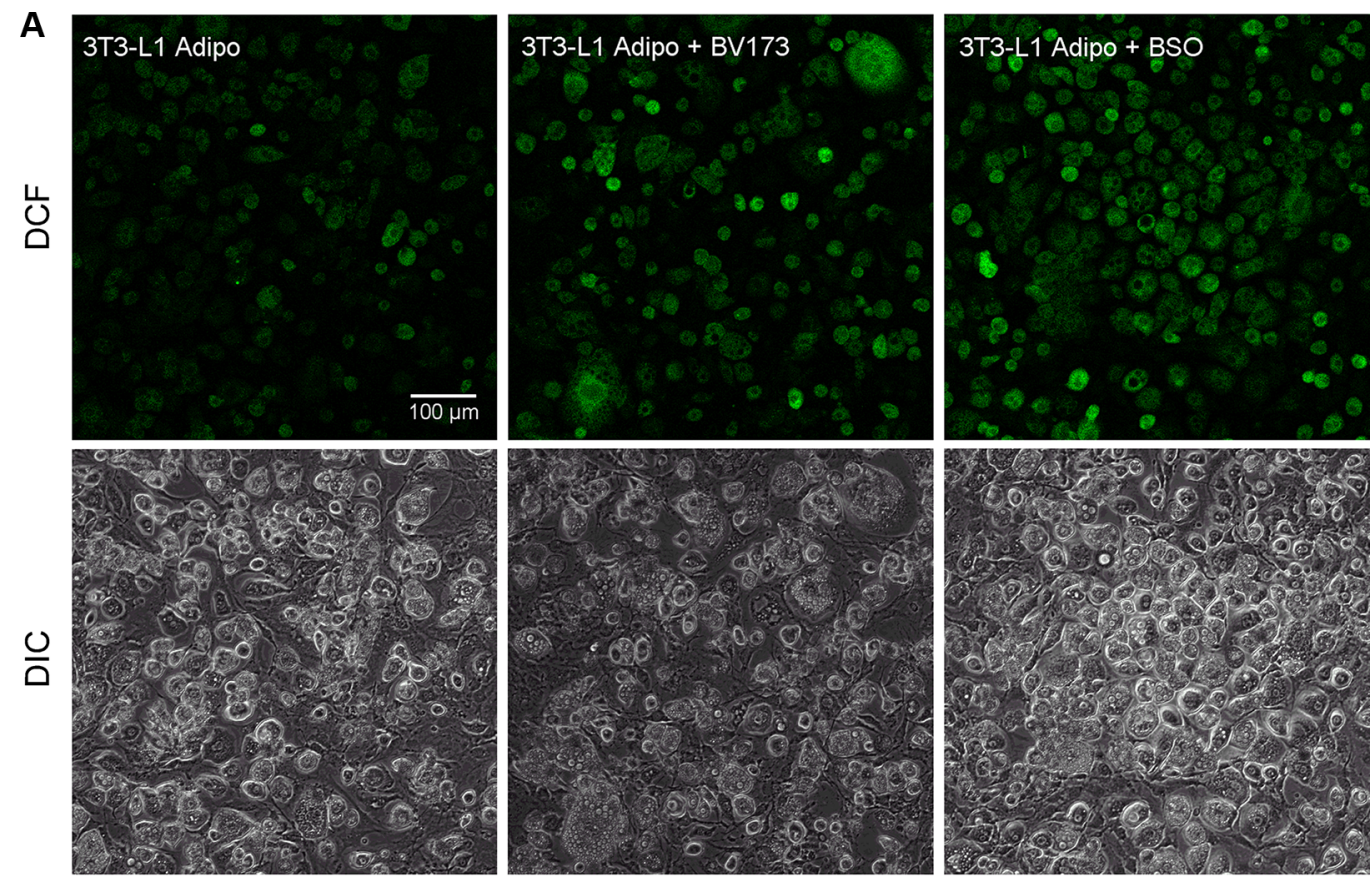

B

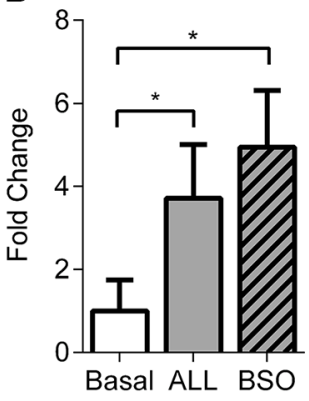

C

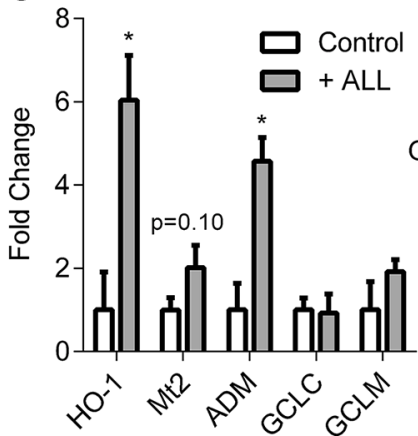

D

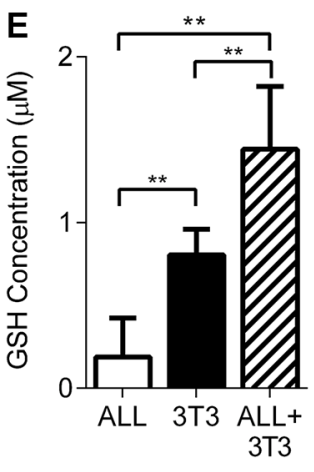

Figure 3: ALL cells induce oxidative stress in adipocytes. (A) Representative fluorescent confocal microscopy images of 3T3-L1 adipocytes alone, with ALL in TransWells, or treated with $20 \mathrm{mM}$ BSO for 48 hours. Top: DCF (green) only, bottom: DIC images. (B) Quantification of fluorescence (FITC) from 3 images similar to A. *indicate $t$-tests on log-transformed pixel counts. (C) 3T3-L1 gene expression by qPCR with (gray bar) and without (white bar) 8093 cells; $n=3$. (D) Western blot of HO-1 expression in 3T3-L1 adipocytes exposed to DNR, ALL, or both. GAPDH was used as loading control. E. GSH levels measured in media after conditioning with BV173 ALL cells, 3T3-L1 adipocytes, or both, for 48 hours. $* P<0.05, * * P<0.01, * * * P<0.001$. 


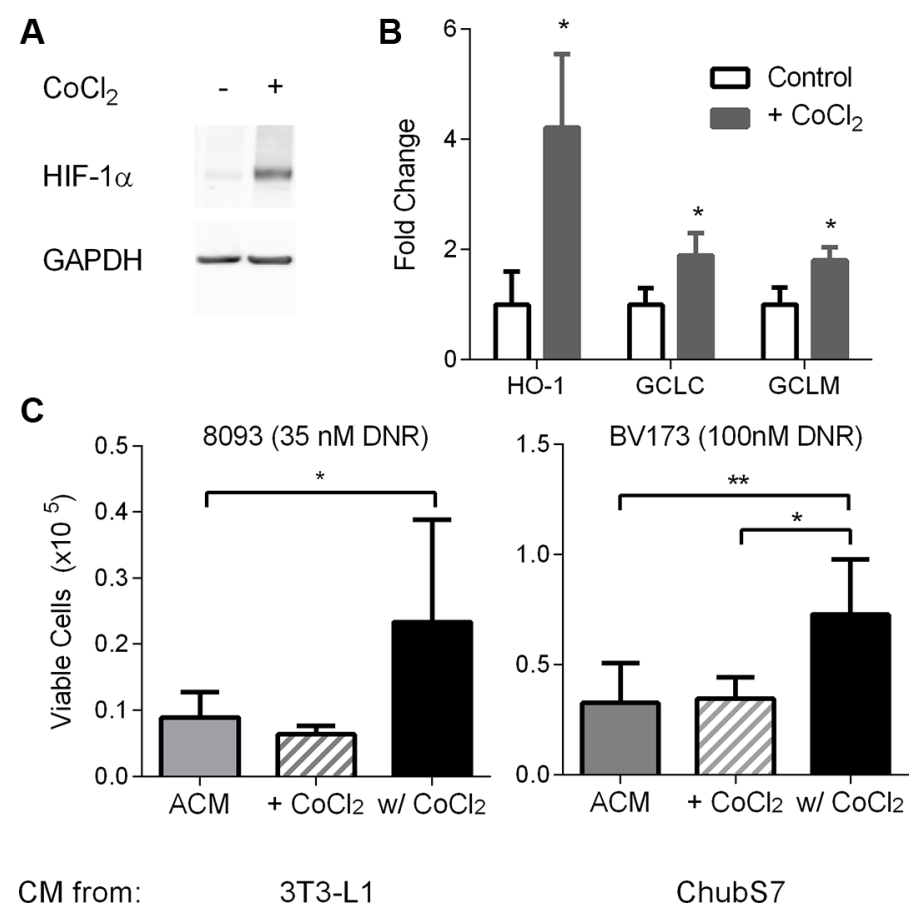

Figure 4: Oxidative stress in adipocytes leads to secretion of survival factors that protect ALL cells from DNR. (A) Representative western blot of HIF-1 $\alpha$ in ChubS7 adipocytes treated with $\mathrm{CoCl}_{2}$. GAPDH was used as loading control. (B) 3T3-L1 gene expression by qPCR with $\mathrm{CoCl}_{2}$ treatment for 24 hours $(n=4)$. (C) Viable cell number of DNR-treated 8093 ALL cells (left) or BV173 cells (right) in the presence of ACM from 3T3-L1 or ChubS7. ACM spiked with $\mathrm{CoCl}_{2}$ were denoted as $\left(+\mathrm{CoCl}_{2}\right)$ and $\mathrm{ACM}$ conditioned in the presence of $30 \mu \mathrm{M} \mathrm{CoCl}_{2}$ as $\left(\mathrm{w} / \mathrm{CoCl}_{2}, n=4-8\right)$. ${ }^{*}<0.05 \mathrm{All}$ asterisks indicate comparison to control conditions unless otherwise indicated.

A

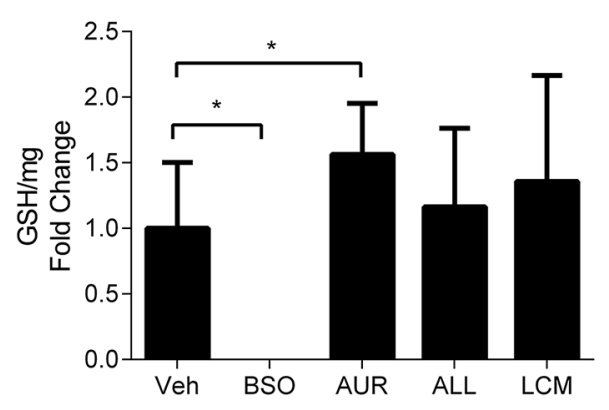

C

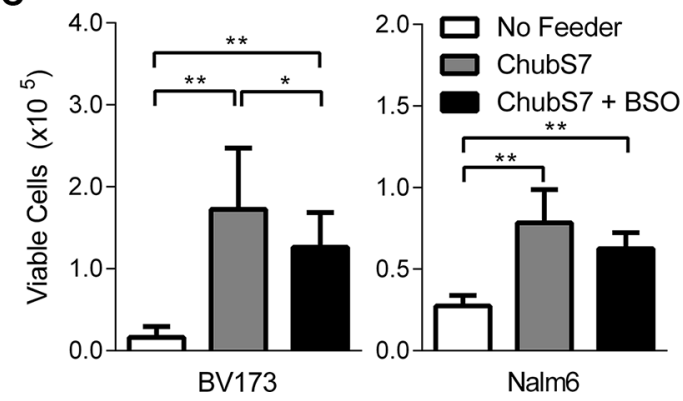

B

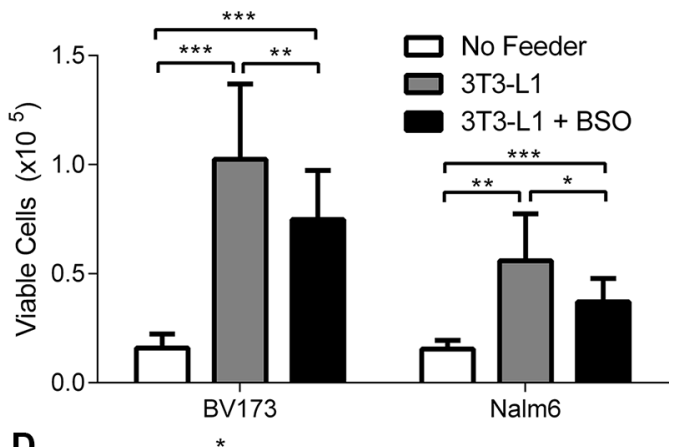

D

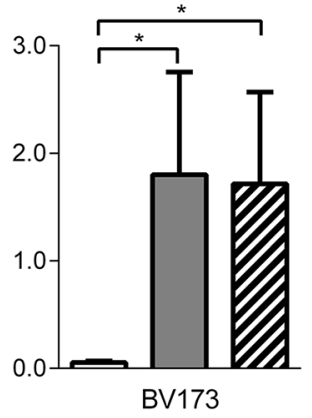

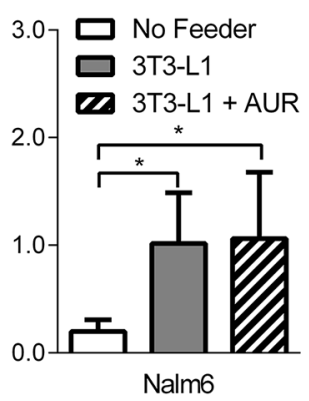

Figure 5: Glutathione synthesis is partially involved in adipocyte protection of ALL cells. (A) Intracellular GSH quantification in 3T3-L1 adipocytes $(n=3)$. Viable cell number of BV173 and Nalm6 cells treated with DNR (100 and $200 \mathrm{nM}$, respectively) while cocultured with 3T3-L1 (B) or ChubS7 (C) adipocytes that were pre-treated with $20 \mathrm{mM}$ BSO for 24 hours $(n=8-10)$. (D) Viable cell number of BV173 and Nalm6 cells treated with DNR while co-cultured with 3T3-L1 adipocytes that were pre-treated with $250 \mathrm{nM}$ AUR for 24 hours $(n=3) .{ }^{*} p<0.05,{ }^{* *} p<0.01,{ }^{* * *} p<0.001$ All asterisks indicate comparison to no feeder or vehicle (Veh) conditions unless otherwise indicated. 
factor in our experimental system. Other adipocytesecreted factors, such as MMP9 and IL8, have been shown to have tumor-promoting effects [4]. Therefore, further investigation is needed to identify which specific factors are responsible for adipocyte protection of ALL cells. Another weakness in the current study is that these results have not been confirmed in primary human ALL cells, nor in vivo. However, the use of multiple human ALL cell lines, coupled with our previous results demonstrating the effects of adipose tissue ex vivo [13], supports the potential importance of these phenomenon to human ALL.

Along with some of our previous studies [13, 16], this work highlights the important role of adipocytes in ALL progression and drug resistance. While adipocyte protection of ALL cells from oxidative stress is one potential mechanisms explaining the association between obesity and poor ALL prognosis [7, 9], there are likely others. Indeed, we have shown that adipocytes protect ALL from multiple chemotherapies [16], some of which do not act through induction of oxidative stress. In addition, we have found that adipocytes absorb some chemotherapies [45], including DNR [46], which could contribute to some of the present results, though would not explain the protection observed from adipocyte conditioned media. Thus, adipocyte protection from oxidative stress should be considered when developing therapeutic strategies which target oxidative stress in cancer cells [41].

\section{MATERIALS AND METHODS}

\section{Chemicals and reagents}

Daunorubicin (DNR), chaetocin (CTN), buthionine sulfoxine (BSO), auranofin (AUR), and other chemicals were obtained from Sigma Aldrich. Cell culture media components, DCFH-DA (dichloro-dihydro-fluorescein diacetate, a fluorimetric probe for oxidative stress assessment), and CellROX ${ }^{\circledR}$ reagent were obtained from Life Technologies. Fetal bovine serum (FBS) was from Denville Scientific. Caspase 3, HIF-1 $\alpha$, and GAPDH antibodies were purchased from Cell Signaling Technologies. HO-1 antibodies were purchased from Abcam.
A

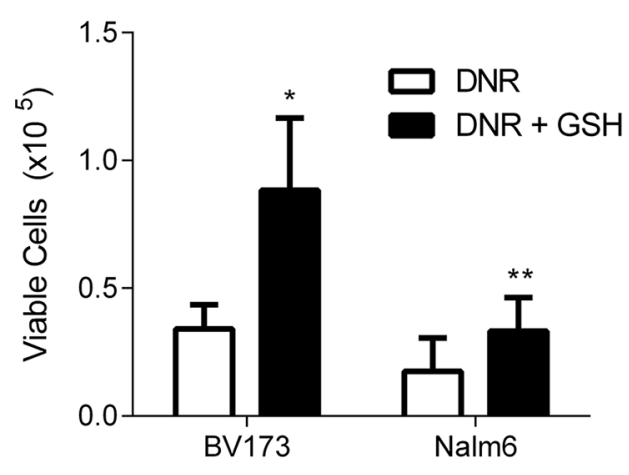

B

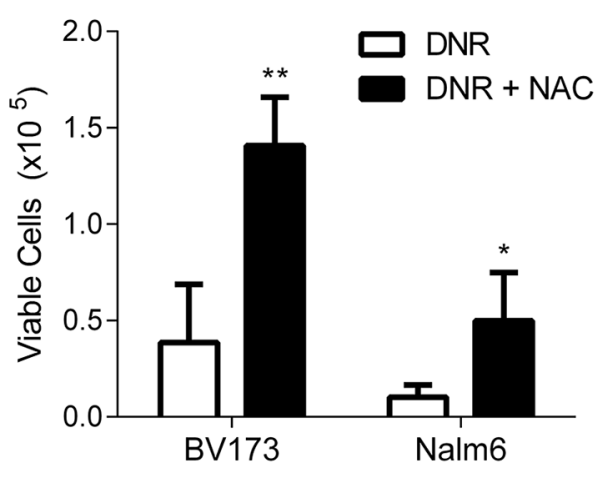

C

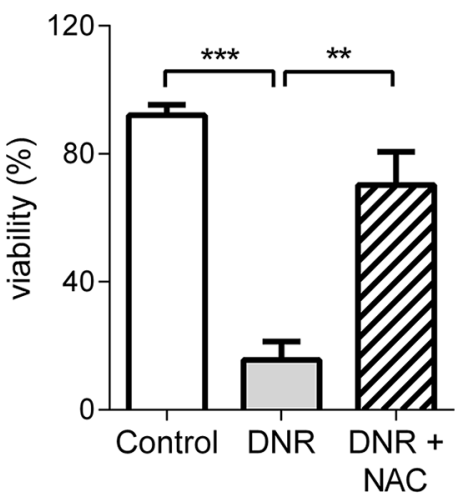

BV173

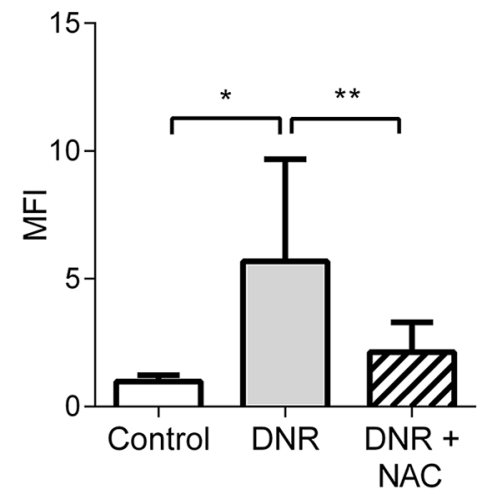

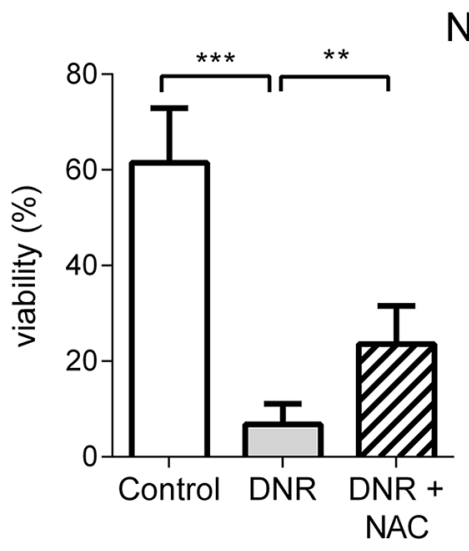

Nalm6

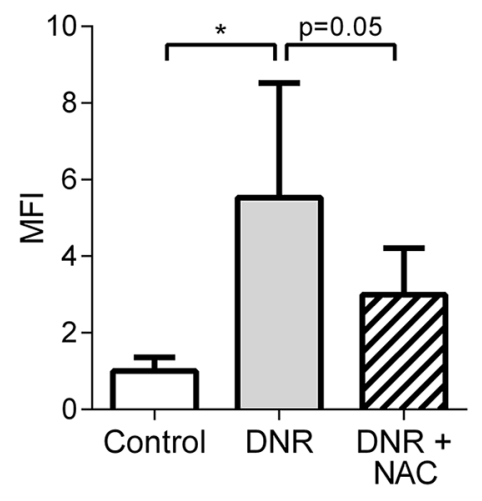

Figure 6: Exogenous antioxidants protect ALL cells from DNR. (A) BV173 and Nalm6 treated with DNR or DNR + GSH (20 mM, n=4). (B) BV173 and Nalm6 treated with DNR or DNR + NAC (20 mM, $n=3-4)$. (C) Cell viability and intracellular ROS evaluation using flow cytometry with DAPI and CellROX ${ }^{\circledR}$ staining of BV173 (top two panels) and Nalm6 (bottom two panels) treated with DNR alone or DNR and NAC $n=5 . * P<0.05, * * P<0.01, * * * P<0.001$ All asterisks indicate comparison to control conditions unless otherwise indicated. 


\section{Cell culture}

All human ALL cell lines (BV173, RS4;11, and Nalm6) and murine pre-adipocyte 3T3-L1 were from ATCC. Murine pre-B 8093 ALL cells have been previously described [16]. Chub-S7 (immortalized human pre-adipose cell line) was from Nestec LTD and cultured as previously described $[47,48]$.

All human ALL cell lines were cultured in RPMI 1640 (Invitrogen), supplemented with 10\% fetal bovine serum (FBS), sodium pyruvate (1 mM), Glutamax ( $2 \mathrm{mM})$, and gentamicin $(10 \mu \mathrm{g} / \mathrm{mL}) .8093$ cells were cultured in McCoy's 5A (Invitrogen), supplemented as above. Fresh recombinant murine interleukin-3 (Peprotech) and betamercaptoethanol (Sigma Aldrich) were added to 8093 cells at each passage. 3T3-L1 cells were cultured in DMEM high glucose (Invitrogen) supplemented with 10\% FBS, sodium pyruvate $(1 \mathrm{mM})$, Glutamax $(2 \mathrm{mM})$, and gentamicin $(10 \mu \mathrm{g} / \mathrm{mL})$. Chub-S7 cells were cultured in DMEM/F12 (Invitrogen) with 10\% FBS, sodium pyruvate $(1 \mathrm{mM})$, Glutamax $(2 \mathrm{mM})$, and gentamicin $(10 \mu \mathrm{g} / \mathrm{mL})$. 3T3-L1 (murine) and ChubS7 (human) pre-adipocytes were differentiated into adipocytes as previously described [48].

Co-culture experiments were performed by seeding ALL cells in chambers of polycarbonate $0.4 \mu \mathrm{m}$ pore size TransWells (Corning Inc., Corning, NY). The TransWells were inserted in plates containing pre-adipocytes or adipocytes, such that the ALL cells were not in physical contact with the feeder cells.

Conditioned media were made with RPMI1640 containing $10 \%$ FBS. Leukemia cell conditioned media (LCM) were made by seeding 200,000 BV173 cells per $\mathrm{mL}$ in culture for 48 hours. Adipocyte conditioned media (ACM) were made by conditioning $100 \mu \mathrm{L} / \mathrm{cm}^{2}$ for 48 hours. Adipocyte leukemia cell conditioned media (ALCM) were made by seeding 200,000 per mL of BV173 in co-culture with a monolayer of adipocytes at $100 \mu \mathrm{L} / \mathrm{cm}^{2}$. All media were filtered upon collection using $0.22 \mu \mathrm{m}$ syringe filters (Millipore) and stored at $-20^{\circ} \mathrm{C}$ until use, avoiding freeze-thaw cycles.

\section{Gene expression profiling}

3T3-L1 adipocytes were cultured in either LCM or regular media for 24 hours in biological triplicates. RNA was extracted and purified using Qiazol reagent and RNEasy Mini Kits as per the manufacturer's (Qiagen) instructions. Microarray hybridization was performed by the Genome Core facility at the Saban Research Institute of Children's Hospital Los Angeles (CHLA). RNA quality was first assessed using an Agilent Bioanalyzer (Agilent Technologies). RNA was then converted to cDNA with Superscript Choice for cDNA Synthesis (Invitrogen) and then converted to biotinylated cDNA using an Enzo High Yield RNA Transcript labeling kit (Enzo Diagnostics). GeneChip ${ }^{\circledR}$ Mouse Gene ST Array (Affymetrix) was used for hybridization of cDNA. Genes that showed significant up/down-regulation $(p<0.05$ compared to control conditions) in LCM treated samples were analyzed using Ingenuity Pathway Analysis (Ingenuity ${ }^{\circledR}$ Systems, www. ingenuity.com).

\section{Real-time PCR}

Cells were collected and stored with RNAProtect (Qiagen) and lyzed with QIAzol (Qiagen). RNA was extracted and purified with RNEasy Mini Kits (Qiagen). The quantity and quality of extracted RNA was measured by NanoVue (Denville Scientific). Two thousand nanograms of RNA from each condition were reverse transcribed to cDNA with a High Capacity 1st Strand Synthesis kit (Applied Biosystems). The expression of selected genes was quantified by qPCR using $25 \mathrm{ng}$ of cDNA, Power SYBR Select PCR Master Mix (Applied Biosystems), and $200 \mathrm{nM}$ primers designed using National Center for Biotechnology Information Primer-BLAST (See Supplementary Table S1 for primer sequences). Gene expression levels were quantified using the ABI $7900 H T$ Sequence Detection System with the following thermal profile: 10 minutes at $95^{\circ} \mathrm{C}$ followed by 40 repeats of $95^{\circ} \mathrm{C}$ for 15 seconds, 60 degrees for 1 minute, and a final dissociation stage of $95^{\circ} \mathrm{C}$ for 15 seconds, $60^{\circ} \mathrm{C}$ for 15 seconds, and $95^{\circ} \mathrm{C}$ for 15 seconds. Transcript levels were normalized to $\beta$-actin. Fold change was calculated using the $\Delta \Delta \mathrm{Ct}$ method.

\section{Confocal microscopy}

The intracellular ROS assay was done by incubating cells with $10 \mu \mathrm{M}$ DCFH-DA for 15 minutes at $37^{\circ} \mathrm{C}$ and then washing with cold PBS. Samples were imaged at the Cellular Imaging Core at the Saban Research Institute of CHLA. Briefly, DCF fluorescence images were acquired with an LSM 700 confocal system mounted on an AxioObserver.Z1 microscope equipped with a $63 \times / 1.4$ Plan-APOCHROMAT objective lens and controlled with ZEN 2009 software (Carl Zeiss Microscopy, Thornwood, NY). A $488 \mathrm{~nm}$ laser and $560 \mathrm{~nm}$ long-pass filter were used for fluorescence excitation and emission. Transmitted laser light was collected to form a DIC image simultaneously with the fluorescence image. Images were histogram-stretched in a consistent manner to increase brightness for publication. Intracellular ROS signals from the images were quantified using ImageJ (National Institute of Health, Bethesda, MD, USA).

\section{Western blots}

Total protein was extracted from cells using protein isolation buffer $(62.5 \mathrm{~mL}$ Tris- $\mathrm{HCL}, 2 \% \mathrm{w} / \mathrm{v}$ SDS, $1 \%$ v/v Igepal CA-630, $10 \%$ glycerol, $0.01 \mathrm{mg} / \mathrm{mL}$ aprotinin, $1 \mathrm{mM}$ phenylmethanesulphonylfluoride, and 
Phosphatase Inhibitor Cocktail Set II (Calcbiochem)). Lysates were sonicated briefly and centrifuged for 10 minutes at $15,000 \mathrm{~g}$ at $4^{\circ} \mathrm{C}$. The supernatant was retained and protein concentration was quantified by BCA assay (Pierce Biotechnology). Equal amounts of protein was subjected to SDS-PAGE and transferred to a nitrocellulose membrane. Membranes were blocked in $5 \%$ milk and then probed with specific primary antibodies. The secondary antibodies used were HRP-linked. Bands were detected using a HyGLO-HRP detection kit (Denville Scientific, South Plainfield, NJ, USA) and developed with HyBLOT-CL Autoradiography Film (Denville Scientific). Densitometric band analysis was performed using ImageJ.

\section{Glutathione measurements}

The GSH-Glo ${ }^{\text {тм }}$ Glutathione Assay (Promega, Madison, WI) was used to measure glutathione (GSH) in media and on cell extracts, following the manufacturer's instructions. The protein amount of each sample was quantified by BCA assay for normalization of GSH.

\section{Flow cytometry}

ALL cells were treated with $10 \mu \mathrm{M}$ DCFH-DA for 15 minutes at $37^{\circ} \mathrm{C}$, then the reaction was stopped by transferring the cells on ice and protecting from light. Then DAPI was added to distinguish live cells. The samples were run at the Fluorescence Activated Cell Sorting Core at CHLA on LSR II Analyzer from Becton Dickinson (BD). The PE channel was used to detect intracellular DNR and the FITC channel for DCF. Proper compensation controls were used to calculate spill over between PE and FITC channels. In other experiments where CellROX ${ }^{\circledR}$ Deep Red Reagent (Life Technologies) was used, the APC channel was used to detect CellROX ${ }^{\circledR}$. For apoptosis analysis, ALL cells were harvested and stained with $25 \mathrm{ng}$ APC-conjugated Annexin V for 15 minutes at room temperature. Then $50 \mathrm{ng}$ DAPI was added to stain for late apoptotic/necrotic cells. The samples were run on the same analyzer above.

\section{Statistical analysis}

All statistical tests were performed with Microsoft Excel 2010. The data are presented as mean \pm Standard Deviation. Experimental groups were compared using paired, two-sided $t$-tests; non-normally distributed data was log-transformed prior to $t$-test. A $p$ value of less than 0.05 was taken as statistically significant. Flow cytometry of intracellular DNR and DCF were quantified using median fluorescence intensity (MFI). MFI was calculated by dividing sample fluorescence signals by the control signal. All experiments were performed in triplicates and repeated at least three times. All graphs are presented as mean $\pm \mathrm{SD}$.

\section{ACKNOWLEDGMENTS}

We would like to thank Dr. Esteban Fernandez at the Imaging Core at CHLA for helping with microscopy and image analyses, Dr. Michael Sheard and Jackie Lin at the Flow Cytometry Core, and Dr. Alfredo Martinez at the Center for Biomedical Research of La Rioja CIBIR for providing the adrenomedullin antibody.

\section{CONFLICTS OF INTEREST}

The authors disclose no potential conflicts of interest.

\section{GRANT SUPPORT}

PHS NIH CA139060 (SDM), CA201444, CA090321 (NH), CA172040 (NH), The Saban Research Institute Pre-doctoral Fellowship (XS), The Shirley McKernan Courage Foundation (SDM), and The V Foundation (SDM and NH).

\section{REFERENCES}

1. Wolin KY, Carson K, Colditz GA. Obesity and Cancer. The Oncologist. 2010; 15:556-65. doi: 10.1634/ theoncologist.2009-0285.

2. Calle EE, Rodriguez C, Walker-Thurmond K, Thun MJ. Overweight, obesity, and mortality from cancer in a prospectively studied cohort of U.S. adults. N Engl J Med. 2003; 348:1625-38. doi: 10.1056/NEJMoa021423.

3. Iyengar P, Combs TP, Shah SJ, Gouon-Evans V, Pollard JW, Albanese C, Flanagan L, Tenniswood MP, Guha C, Lisanti MP, Pestell RG, Scherer PE. Adipocyte-secreted factors synergistically promote mammary tumorigenesis through induction of anti-apoptotic transcriptional programs and proto-oncogene stabilization. Oncogene. 2003; 22:6408-23. doi: 10.1038/sj.onc.1206737.

4. Nieman KM, Kenny HA, Penicka CV, Ladanyi A, BuellGutbrod R, Zillhardt MR, Romero IL, Carey MS, Mills GB, Hotamisligil GS, Yamada SD, Peter ME, Gwin K, et al. Adipocytes promote ovarian cancer metastasis and provide energy for rapid tumor growth. Nat Med. 2011; 17 : 1498-503. doi: 10.1038/nm.2492.

5. Masoodi M, Lee E, Eiden M, Bahlo A, Shi Y, Ceddia RB, Baccei C, Prasit P, Spaner DE. A role for oleoylethanolamide in chronic lymphocytic. Leukemia. 2014; 28:1381-7. doi: 10.1038/leu.2014.10.

6. Tung S, Shi Y, Wong K, Zhu F, Gorczynski R, Laister RC, Minden M, Blechert AK, Genzel Y, Reichl U, Spaner DE. PPAR $\alpha$ and fatty acid oxidation mediate glucocorticoid resistance in chronic lymphocytic leukemia. Blood. 2013; 122:969-80. doi: 10.1182/blood-2013-03-489468. 
7. Butturini AM, Dorey FJ, Lange BJ, Henry DW, Gaynon PS, Fu C, Franklin J, Siegel SE, Seibel NL, Rogers PC, Sather H, Trigg M, Bleyer WA, et al. Obesity and Outcome in Pediatric Acute Lymphoblastic Leukemia. J Clin Oncol. 2007; 25:2063-9. doi: 10.1200/JCO.2006.07.7792.

8. Amankwah EK, Saenz AM, Hale GA, Brown PA. Association between body mass index at diagnosis and pediatric leukemia mortality and relapse: a systematic review and meta-analysis. Leuk Lymphoma. 2015; 0:1-9. doi: 10.3109/10428194.2015.1076815.

9. Orgel E, Genkinger JM, Aggarwal D, Sung L, Nieder M, Ladas EJ. Association of body mass index and survival in pediatric leukemia: a meta-analysis. Am J Clin Nutr. 2016; 103:808-17. doi: 10.3945/ajcn.115.124586.

10. Nguyen T-V, Melville A, Nath S, Story C, Howell S, Sutton R, Zannettino A, Revesz T. Bone Marrow Recovery by Morphometry during Induction Chemotherapy for Acute Lymphoblastic Leukemia in Children. PLoS One. 2015; 10:e126233. doi: 10.1371/journal.pone.0126233.

11. Battula VL, Chen Y, Cabreira M da G, Ruvolo V, Wang Z, Ma W, Konoplev S, Shpall E, Lyons K, Strunk D, BuesoRamos C, Davis RE, Konopleva M, et al. Connective tissue growth factor regulates adipocyte differentiation of mesenchymal stromal cells and facilitates leukemia bone marrow engraftment. Blood. 2013; 122:357-66. doi: 10.1182/blood-2012-06-437988.

12. Chen T. Morphology, differentiation and adhesion molecule expression changes of bone marrow mesenchymal stem cells from acute myeloid leukemia patients. Mol Med Rep. 2013 [cited 2015 Aug 5]; doi: 10.3892/mmr.2013.1789.

13. Pramanik R, Sheng X, Ichihara B, Heisterkamp N, Mittelman SD. Adipose tissue attracts and protects acute lymphoblastic leukemia cells from chemotherapy. Leuk Res. 2013; 37:503-9. doi: 10.1016/j.leukres.2012.12.013.

14. Maitra A, McKenna RW, Weinberg AG, Schneider NR, Kroft SH. Precursor B-Cell Lymphoblastic Lymphoma A Study of Nine Cases Lacking Blood and Bone Marrow Involvement and Review of the Literature. Am J Clin Pathol. 2001; 115:868-75.

15. Lozzi GP, Massone C, Citarella L, Kerl H, Cerroni L. Rimming of adipocytes by neoplastic lymphocytes: a histopathologic feature not restricted to subcutaneous T-cell lymphoma. Am J Dermatopathol. 2006; 28:9-12. doi: 10.1097/01.dad.0000187933.87103.03.

16. Behan JW, Yun JP, Proektor MP, Ehsanipour EA, Arutyunyan A, Moses AS, Avramis VI, Louie SG, Butturini A, Heisterkamp N, Mittelman SD. Adipocytes Impair Leukemia Treatment in Mice. Cancer Res. 2009; 69:7867-74. doi: 10.1158/0008-5472.CAN-09-0800.

17. Ehsanipour EA, Sheng X, Behan JW, Wang X, Butturini A, Avramis VI, Mittelman SD. Adipocytes Cause Leukemia Cell Resistance to 1-Asparaginase via Release of Glutamine. Cancer Res. 2013 [cited 2013 May 4]; . doi: 10.1158/00085472.CAN-12-4402.

18. Gorrini C, Harris IS, Mak TW. Modulation of oxidative stress as an anticancer strategy. Nat Rev Drug Discov. 2013; 12:931-47. doi: 10.1038/nrd4002.
19. Singh A, Misra V, Thimmulappa RK, Lee H, Ames S, Hoque MO, Herman JG, Baylin SB, Sidransky D, Gabrielson E, Brock MV, Biswal S. Dysfunctional KEAP1NRF2 Interaction in Non-Small-Cell Lung Cancer. PLoS Med. 2006; 3:e420. doi: 10.1371/journal.pmed.0030420.

20. Sauer H, Wartenberg M, Hescheler J. Reactive Oxygen Species as Intracellular Messengers During Cell Growth and Differentiation. Cell Physiol Biochem. 2001; 11:173-86. doi: 10.1159/000047804.

21. D'Autréaux B, Toledano MB. ROS as signalling molecules: mechanisms that generate specificity in ROS homeostasis. Nat Rev Mol Cell Biol. 2007; 8:813-24. doi: 10.1038/nrm2256.

22. Itoh K, Chiba T, Takahashi S, Ishii T, Igarashi K, Katoh Y, Oyake T, Hayashi N, Satoh K, Hatayama I, Yamamoto M, Nabeshima Y. An Nrf2/Small Maf Heterodimer Mediates the Induction of Phase II Detoxifying Enzyme Genes through Antioxidant Response Elements. Biochem Biophys Res Commun. 1997; 236:313-22. doi: 10.1006/ bbrc.1997.6943.

23. Lu SC. Glutathione synthesis. Biochim Biophys Acta. 2013; 1830:3143-53. doi: 10.1016/j.bbagen.2012.09.008.

24. Zhe N, Wang J, Chen S, Lin X, Chai Q, Zhang Y, Zhao J, Fang Q. Heme oxygenase-1 plays a crucial role in chemoresistance in acute myeloid leukemia. Hematology. 2014; 20:384-91. doi: 10.1179/1607845414Y.0000000212.

25. Sharma A, Patrick B, Li J, Sharma R, Jeyabal PVS, Reddy PMRV, Awasthi S, Awasthi YC. Glutathione S-transferases as antioxidant enzymes: Small cell lung cancer (H69) cells transfected with hGSTA1 resist doxorubicin-induced apoptosis. Arch Biochem Biophys. 2006; 452:165-73. doi: 10.1016/j.abb.2006.04.006.

26. Heisterkamp N, Jenster G, ten Hoeve J, Zovich D, Pattengale PK, Groffen J. Acute leukaemia in bcr/ abl transgenic mice. Nature. 1990; 344:251-3. doi: 10.1038/344251a0.

27. Conklin KA. Chemotherapy-Associated Oxidative Stress: Impact on Chemotherapeutic Effectiveness. Integr Cancer Ther. 2004; 3:294-300. doi: 10.1177/1534735404270335.

28. Huang B-W, Miyazawa M, Tsuji Y. Distinct regulatory mechanisms of the human ferritin gene by hypoxia and hypoxia mimetic cobalt chloride at the transcriptional and post-transcriptional levels. Cell Signal. 2014; 26:2702-9. doi: 10.1016/j.cellsig.2014.08.018.

29. Iyengar P, Espina V, Williams TW, Lin Y, Berry D, Jelicks LA, Lee H, Temple K, Graves R, Pollard J, Chopra N, Russell RG, Sasisekharan R, et al. Adipocytederived collagen VI affects early mammary tumor progression in vivo, demonstrating a critical interaction in the tumor/stroma microenvironment. J Clin Invest. 2005; 115:1163-76. doi: 10.1172/JCI23424.

30. Choe C, Shin Y, Choi S-J, Lee J, Kim S, Cho YB, Kim J, Kim C. Crosstalk with cancer-associated fibroblasts induces resistance of non-small cell lung cancer cells to epidermal growth factor receptor tyrosine kinase inhibition. OncoTargets Ther. 2015; 3665. doi: 10.2147/OTT.S89659.

31. Orimo A, Gupta PB, Sgroi DC, Arenzana-Seisdedos F, Delaunay $\mathrm{T}$, Naeem R, Carey VJ, Richardson AL, 
Weinberg RA. Stromal Fibroblasts Present in Invasive Human Breast Carcinomas Promote Tumor Growth and Angiogenesis through Elevated SDF-1/CXCL12 Secretion. Cell. 2005; 121:335-48. doi: 10.1016/j.cell.2005.02.034.

32. Fiaschi T, Marini A, Giannoni E, Taddei ML, Gandellini P, Donatis AD, Lanciotti M, Serni S, Cirri P, Chiarugi P. Reciprocal Metabolic Reprogramming through Lactate Shuttle Coordinately Influences Tumor-Stroma Interplay. Cancer Res. 2012; 72:5130-40. doi: 10.1158/0008-5472. CAN-12-1949.

33. Martinez-Outschoorn UE, Lin Z, Trimmer C, Flomenberg N, Wang C, Pavlides S, Pestell RG, Howell A, Sotgia F, Lisanti MP. Cancer cells metabolically "fertilize" the tumor microenvironment with hydrogen peroxide, driving the Warburg effect. Cell Cycle. 2011; 10:2504-20. doi: $10.4161 /$ cc.10.15.16585.

34. Dirat B, Bochet L, Dabek M, Daviaud D, Dauvillier S, Majed B, Wang YY, Meulle A, Salles B, Gonidec SL, Garrido I, Escourrou G, Valet P, et al. Cancer-Associated Adipocytes Exhibit an Activated Phenotype and Contribute to Breast Cancer Invasion. Cancer Res. 2011; 71:2455-65. doi: 10.1158/0008-5472.CAN-10-3323.

35. Bochet L, Meulle A, Imbert S, Salles B, Valet P, Muller C. Cancer-associated adipocytes promotes breast tumor radioresistance. Biochem Biophys Res Commun. 2011; 411:102-6. doi: 10.1016/j.bbrc.2011.06.101.

36. Nieman KM, Romero IL, Van Houten B, Lengyel E. Adipose tissue and adipocytes support tumorigenesis and metastasis. Biochim Biophys Acta BBA - Mol Cell Biol Lipids. 2013; 1831:1533-41. doi: 10.1016/j. bbalip.2013.02.010.

37. Guerrero J, Tobar N, Cáceres M, Espinoza L, Escobar P, Dotor J, Smith PC, Martínez J. Soluble factors derived from tumor mammary cell lines induce a stromal mammary adipose reversion in human and mice adipose cells. Possible role of TGF- $\beta 1$ and TNF- $\alpha$. Breast Cancer Res Treat. 2010; 119:497-508. doi: 10.1007/s10549-009-0491-1.

38. Andarawewa KL, Motrescu ER, Chenard M-P, Gansmuller A, Stoll I, Tomasetto C, Rio M-C. Stromelysin-3 Is a Potent Negative Regulator of Adipogenesis Participating to Cancer Cell-Adipocyte Interaction/Crosstalk at the Tumor Invasive Front. Cancer Res. 2005; 65:10862-71. doi: 10.1158/0008-5472.CAN-05-1231.

39. Truitt L, Hutchinson C, DeCoteau JF, Geyer CR. Chaetocin antileukemia activity against chronic myelogenous leukemia cells is potentiated by bone marrow stromal factors and overcomes innate imatinib resistance. Oncogenesis. 2014; 3:e122. doi: 10.1038/oncsis.2014.37.
40. Fiskus W, Saba N, Shen M, Ghias M, Liu J, Gupta SD, Chauhan L, Rao R, Gunewardena S, Schorno K, Austin CP, Maddocks K, Byrd J, et al. Auranofin induces lethal oxidative and endoplasmic reticulum stress and exerts potent preclinical activity against chronic lymphocytic leukemia. Cancer Res. 2014; 74:2520-32. doi: 10.1158/0008-5472.CAN-13-2033.

41. Harris IS, Treloar AE, Inoue S, Sasaki M, Gorrini C, Lee KC, Yung KY, Brenner D, Knobbe-Thomsen CB, Cox MA, Elia A, Berger T, Cescon DW, et al. Glutathione and Thioredoxin Antioxidant Pathways Synergize to Drive Cancer Initiation and Progression. Cancer Cell. [cited 2015 Feb 6]; doi: 10.1016/j.ccell.2014.11.019.

42. Boutter J, Huang Y, Marovca B, Vonderheit A, Grotzer MA, Eckert C, Cario G, Wollscheid B, Horvath P, Bornhauser BC, Bourquin J-P. Image-based RNA interference screening reveals an individual dependence of acute lymphoblastic leukemia on stromal cysteine support. Oncotarget. 2014; 5:11501-12. doi: 10.18632/ oncotarget.2572.

43. Li Y, Jiang C, Wang X, Zhang Y, Shibahara S, Takahashi K. Adrenomedullin is a novel adipokine: Adrenomedullin in adipocytes and adipose tissues. Peptides. 2007; 28:1129-43. doi: 10.1016/j.peptides.2007.03.005.

44. Cuttitta F, Pío R, Garayoa M, Zudaire E, Julián M, Elsasser TH, Montuenga LM, Martínez A. Adrenomedullin functions as an important tumor survival factor in human carcinogenesis. Microsc Res Tech. 2002; 57:110-119. doi: 10.1002/jemt.10059.

45. Behan JW, Avramis VI, Yun JP, Louie SG, Mittelman SD. Diet-induced obesity alters vincristine pharmacokinetics in blood and tissues of mice. Pharmacol Res. 2010; 61:385-90. doi: 10.1016/j.phrs.2010.01.007.

46. Sheng X, Tucci J, Behan J, Mittelman SD. Abstract 172: Adipocytes decrease daunorubicin concentration in acute lymphoblastic leukemia cells. Cancer Res. 2014; 74:172-172. doi: 10.1158/1538-7445.AM2014-172.

47. Darimont C, Zbinden I, Avanti O, Leone-Vautravers P, Giusti V, Burckhardt P, Pfeifer AMA, Macé K. Reconstitution of telomerase activity combined with HPV-E7 expression allow human preadipocytes to preserve their differentiation capacity after immortalization. Cell Death Differ. 2003; 10:1025-31. doi: 10.1038/ sj.cdd.4401273.

48. Sheng X, Tucci J, Malvar J, Mittelman SD. Adipocyte differentiation is affected by media height above the cell layer. Int J Obes. 2013 [cited 2013 Dec 29]; doi: 10.1038/ ijo.2013.96. 